\title{
Leaks and the Limits of Press Freedom
}

\section{Eric R. Boot ${ }^{1}$}

Accepted: 21 May 2019 / Published online: 5 June 2019

(C) The Author(s) 2019

\begin{abstract}
Political philosophical work on whistleblowing has thus far neglected the role of journalists. A curious oversight, given that the whistleblower's objective - informing the public about government wrongdoing - can typically not be realized without the media. The present article, therefore, aims to start remedying this neglect by exploring some of the most pressing questions. Accordingly, the paper will be structured as follows: Section 1 will explain why the authorities have treated whistleblowers far more harshly than the journalists who publish their disclosures. Still, the freedom of expression of media workers is (and ought to be) less extensive than that of ordinary individuals. Section 2 will explain why by arguing that the freedom of expression of the press, contrary to that of individuals, is not an unconditional good; instead, it is good merely instrumentally. Section 3 considers and refutes an argument for a more expansive press freedom based on the marketplace of ideas model and, in doing so, also discusses some important differences between the ethics of the traditional and the new online media. Often journalists, like whistleblowers, will justify their publications based on leaked classified documents by appealing to the public interest. Yet, this is problematic for two reasons: (1) the public interest is never clarified; and (2) this argument overlooks the fact that the public interest can also be a reason for not publishing about leaked classified documents, even if the leaks are verified (in the interest of national security, for example). Accordingly, Section 5 sets out to clarify the public interest. Section 4 then discusses two case studies - one concerning unverified leaks, and one concerning verified leaks - in order to demonstrate how we might employ the concept of the public interest in order to determine the permissibility of publishing about leaked classified information in practice.
\end{abstract}

Keywords Leaks $\cdot$ Press freedom $\cdot$ Whistleblowing $\cdot$ Public interest

Eric R. Boot

e.r.boot@uu.nl; https://www.uu.academia.edu/EricBoot

1 Department of Philosophy and Religious Studies, Utrecht University, Janskerkhof 13, 3512

BL Utrecht, the Netherlands 
Though it may be true that some of the most prominent cases of whistleblowing occurred just this past decade, still the recent trickle of papers on the subject by political philosophers was long overdue. ${ }^{1}$ A lot of work remains to be done, but at least political philosophers are slowly but surely making up for their protracted silence on whistleblowing. Thus far, philosophical discussions of unauthorized disclosures of classified government ${ }^{2}$ information have focused on the whistleblower and her actions: What are whistleblowers' obligations with regard to classified government documents, given that they are often government employees themselves? Under what conditions is disclosure justified? In what manner ought classified information to be disclosed (e.g., only after having diligently edited the information prior to publication)? These discussions have largely neglected, however, to consider the role of journalists. A curious oversight, given that the whistleblower's objective - ideally: informing the public about what she believes or suspects to be government wrongdoing - can typically not be realized without help from the media. The present article, therefore, aims to begin remedying this neglect by asking some of the most pressing questions, namely "What accounts for the difference in treatment by the authorities of whistleblowers and the journalists who publish their stories?" and "What, if any, are the restrictions of press freedom, both in general and specifically concerning the treatment of leaked documents?"

Accordingly, the paper will be structured as follows: Section 1 will explain why the authorities have treated whistleblowers far more harshly than the journalists who publish their disclosures. Still, the freedom of expression of media workers is (and ought to be) less extensive than that of ordinary individuals. Section 2 will explain why by arguing that the freedom of expression of the press, contrary to that of individuals, is not an unconditional good; instead, it is good merely instrumentally. Section 3 considers and refutes an argument for a more expansive press freedom based on the marketplace of ideas model and, in doing so, also discusses some important differences between the ethics of the traditional and the new online media.

Journalists who employ methods that seem morally problematic - such as publishing articles about leaked state secrets -, like the whistleblowers who passed the information on to them, often appeal to the public interest in order to justify their actions. What exactly is meant by "the public interest" is, however, never clarified. Therefore, Section 4 clarifies this concept by, first, discussing the three most common public interest theories and, second, expounding a new, more convincing theory of the public interest: the civic theory. Though the public interest is often invoked to justify publishing leaked classified information, I will argue that it can equally well compel the media to refrain from publishing (in the interest of national security, for example). Finally, Section 5 discusses two leaks - one containing unverified information and one containing verified information - in order to demonstrate how we might employ the concept of the public interest in order to determine the permissibility of publishing about leaked classified information in practice. If the publication is deemed to harm the public interest more than benefit it, then it ought not to be protected by the press's freedom of expression.

\footnotetext{
${ }^{1}$ See, e.g., Boot 2017; Delmas 2015; Kumar and Santoro 2017; Sagar 2013; Scheuerman 2014; Shiffrin 2017.

2 I will largely leave whistleblowing cases from the corporate world to one side.
} 


\section{Difference in Treatment}

Back in 2007, the American legal scholar Geoffrey R. Stone stated that the United States government has never in its history prosecuted a member of the press for publishing classified government information (Stone 2007). Since then, it has also refrained from prosecuting the journalists from such media outlets as The Guardian and The New York Times who published the information leaked by Chelsea (then Bradley) Manning and Edward Snowden. At the same time, however, Manning was sentenced to a 35-years prison term (later commuted by President Obama to nearly seven years), Thomas Drake was indicted under the Espionage Act (though a year later the government dropped all charges against him), and Edward Snowden was charged with two counts of violating the Espionage Act. How can we account for this difference in treatment?

It might be explained by the observation that civil servants are bound by two obligations that journalists are not, which render their unauthorized disclosure (at least pro tanto) wrongful, namely promissory obligations and role obligations. Regarding the former, civil servants often swear an oath to the effect that they will respect the classified nature of certain documents they encounter at work. Accordingly, public disclosure of those documents constitutes a violation of the civil servant's obligation to keep her promise. Regarding the latter, a common understanding of civil servants' role obligations is that they ought to dutifully follow their superiors' instructions, whereby their political preferences or moral convictions are to play no part. ${ }^{3}$ Civil servants should be impartial and serve different administrations equally well, even if they personally disapprove of a given law or policy. As role obligations' normative force originates in the role itself Hardimon (1994) and does thus not rely on external moral justification, it is possible for civil servants, as role agents, to be obligated to perform acts they personally consider to be wrongful. In such cases, the norms of their institutional role command them to perform acts, which they reject on the basis of external moral norms. Thus, when a civil servant decides to disregard her superior's designation of certain documents as classified and proceeds to render the information contained therein public, she is violating her role obligation, rendering her action wrongful.

Of course, one can imagine situations in which there are strong moral reasons in favor of whistleblowing - chiefly, to inform the public of grave government wrongdoing. Accordingly, it makes sense to view the obligation to refrain from whistleblowing as a pro tanto obligation that may be defeated by countervailing moral reasons. But what concerns us here is identifying the obligations of civil servants concerning the treatment of classified information that set them apart from members of the Fourth Estate.

So, do these wrong-making reasons also apply to journalists publishing classified information? It is clear that members of the press do not share the role obligations that civil servants have freely taken on when they accepted the job. The same goes for promissory obligations: civil servants have promised to accept certain limitations on their right to free speech (namely not to speak about classified information). Journalists have made no such promise. ${ }^{4}$ Being bound by these two sets of obligations they have freely taken on, it seems justified to grant

\footnotetext{
${ }^{3}$ Consider, for example, the following passage from Max Weber: "The honor of the civil servant is vested in his ability to execute conscientiously the order of the superior authorities, exactly as if the order agreed with his own conviction. This holds even if the order appears wrong to him and if, despite the civil servant's remonstrances, the authority insists on the order. Without this moral discipline and self-denial, in the highest sense, the whole apparatus would fall to pieces" (Weber 1991. 95). Cf. Quinlan 1993.

${ }^{4}$ Cf. Stone 2007. 191.
} 
civil servants a more limited freedom of expression than the journalists with whom they collaborate (who are not constrained by these obligations).

But, if journalists are not bound by the same obligations that prohibit civil servants from publishing classified material, ${ }^{5}$ are we to conclude that they are therefore free to publish any and all government information leaked to them? In the following section, I will argue that they are not and that media companies and their employees in fact (ought to) enjoy a less extensive freedom of expression than ordinary individuals. ${ }^{6}$

\section{Restrictions on Press Freedom}

In the Anglo-American tradition, freedom of speech tends to be seen as absolute. The First Amendment to the American Constitution unqualifiedly states that "Congress shall make no law... abridging the freedom of speech, or of the press." In similar absolute terms, John Stuart Mill argued in favor of "absolute freedom of opinion and sentiment on all subjects, practical or speculative, scientific, moral or theological," adding that the "liberty of expressing and publishing opinions" is "practically inseparable from it" (Mill 2008a). Indeed, American legal scholars seem to agree that the right to freedom of speech protects disclosures of official secrets by the press from criminal punishment unless the disclosure would result in "likely, imminent, and serious harm to the national security" that is, furthermore, "specific" and "identifiable" (Kitrosser 2008. 928). Some add that the disclosure must even have been intended to cause the imminent and serious harm. ${ }^{8}$

Legally, therefore, there are not many restrictions on the press's freedom of speech and publication, at least in the American setting. The situation is somewhat different, however, in Europe. Article 10(2) of the European Convention on Human Rights (ECHR) clearly states that the exercise of the right to freedom of speech comes with "duties and responsibilities" to exercise the right responsibly. Accordingly, the exercise of the right

may be subject to such formalities, conditions, restrictions or penalties as are prescribed by law and are necessary in a democratic society, in the interests of national security, territorial integrity or public safety, for the prevention of disorder or crime, for the protection of health or morals, for the protection of the reputation or rights of others, for preventing the disclosure of information received in confidence, or for maintaining the authority and impartiality of the judiciary.

Next to these limitations that are inherent to the very right itself, the ECHR also contains Article 17, the so-called 'abuse clause.' This article consists in a general prohibition of the abuse of the rights listed in the Convention. ${ }^{9}$ Usually this article is used indirectly, that is, by

\footnotetext{
${ }^{5}$ Indeed, they might instead be considered role-obligated to publish such material - if it serves the public interest - and to protect their sources who leak such material to them. See, e.g., Harris 1990.

${ }^{6}$ So civil servants, journalists and ordinary citizens have an ever-larger scope of freedom of expression.

${ }^{7}$ Stone 2007. 204; cf. Benkler 2011. 353.

${ }^{8}$ Greenawalt 2016. 355; cf. Kitrosser 2008. 928. Stone, by contrast, sets the bar somewhat lower by arguing that the publisher knew the disclosure of the classified information would likely result in grave and imminent harm (Stone 2007. 204).

9 "Nothing in this Convention may be interpreted as implying for any State, group or person any right to engage in any activity or perform any act aimed at the destruction of any of the rights and freedoms set forth herein or at their limitation to a greater extent than is provided for in the Convention."
} 
applying it together with another article - Article 10(2), for example -, in order to decide whether or not a particular limitation of freedom of expression is legitimate. In certain cases, however, the abuse clause is used in a direct manner, "categorically excluding certain expressions from the protection of Article 10" (Cannie and Voorhoof 2011. 58). This last approach is particularly common when the Court has to deal with instances of hate speech that undermine the central values of the Convention itself by expressing racist, xenophobic, antiSemitic, and aggressively nationalistic views, as well as views that are discriminatory towards minorities and immigrants. ${ }^{10}$ Thus in Pavel Ivanov v. Russia, for example, the Court held that Ivanov's anti-Semitic remarks did not enjoy protection under Article 10: "Such a general and vehement attack on one ethnic group is in contradiction with the Convention's underlying values, notably tolerance, social peace and non-discrimination." 11

In addition to these restrictions of the right to freedom of expression that can be found in Article 10(2) and in the general prohibition of the abuse of rights in Article 17, the case law of the Court has shown that certain professionals (such as journalists) have special obligations with regard to the exercise of their right to freedom of expression:

Hence, the safeguard afforded by Article 10 to journalists in relation to reporting on issues of general interest is subject to the proviso that they are acting in good faith and on an accurate factual basis and provide "reliable and precise" information in accordance with the ethics of journalism ... ${ }^{12}$

Specifically with regard to journalists, the Court thus several conditions to the enjoyment of the right to free speech. This means the media's freedom of speech is in fact more limited than that of ordinary individuals. With good reason, I would argue. The reason is as follows: we have good autonomy-based reasons for recognizing a very expansive right to freedom of expression for individuals, even when the opinions they express are false, misguided or simply absurd. This is because our reasons for recognizing this right do not so much depend on the value of what is said but rather on the value of being able to express oneself freely. Such a justification of the right to freedom of expression, however, does not seem to apply to (media) institutions. Powerful (media) institutions are not typically granted an unbridled freedom of expression, as O’Neill notes:

The communication of governments, companies, public bodies and universities (for example) is properly constrained by requirements for accountability and disciplined by freedom of information legislation; academic freedom is constrained by practices such as peer review and demands for research integrity. Why then should the businesses that control newspapers or radio and TV channels enjoy unfettered freedom of expression? Why should the powerful media conglomerates controlled by Rupert Murdoch or Silvio Berlusconi have the same freedom of expression as the vulnerable individuals whom conventions and constitutions are designed to protect? (O’Neill 2008)

\footnotetext{
${ }^{10}$ Recommendation No. R 97 (20) of the Committee of Ministers of the Council of Europe on "hate speech" (adopted on 30 October 1997). Available at: http://www.coe.int/t/dghl/standardsetting/hrpolicy/other_ committees/dh-lgbt_docs/CM_Rec(97)20_en.pdf.

${ }_{11}^{11}$ ECtHR. Pavel Ivanov v. Russia. 20 February 2007. Application No. 35222/04 (decision).

${ }^{12}$ ECtHR (Grand Chamber). Stoll v. Switzerland. 10 December 2007. Application No. 69698/01. § 103 cf. ECtHR (Grand Chamber). Case of Springer v. Germany. 7 February 2012. Application No. 39954/08. § 93.
} 
The scope of individuals' freedom of expression and that of institutions, including media companies, are thus not coextensive. The reason for this is that contrary to the case of individuals, we do not have strong intrinsic, autonomy-based reasons ${ }^{13}$ for recognizing the right to freedom of expression of media companies and their employees. Instead, freedom of the press is an instrumental and thus conditional good. ${ }^{14}$ It is good insofar as it plays its democratic role, namely to inform the public of matters of public concern, so that the public can, in turn, exercise its democratic rights in a well-informed manner. If, instead, a media publication misleads the public (either in order to manipulate the public or simply for financial gain), then the instrumental argument for recognizing its right to freedom of expression disappears, warranting restrictions of that right. We have no reason to believe that the right to freedom of the press involves a right to deceive or misinform. Deception and misinformation, after all, limit citizens' ability to make informed decisions and to hold their representatives to account. They thus form a considerable threat to democracy.

\section{The Case for a more Expansive Press Freedom: Refuted}

Members of the traditional press believe that what sets them apart from the new online media is their filtering process: they check the facts, follow up sources, and verify the information before publishing it. They want to get the news right, before proceeding to publish. They believe that this modus operandi leads to a qualitatively better and more reliable product than that provided by online competitors. Online, instead, speed is more important. The mantra there is "publish, then filter," whereas the traditional media filter, then publish (Ward 2011. 214). Online, accuracy is believed to reside in transparency. The new online media compensate for the uncertain accuracy by posting disclaimers at the start of the article, warning the reader of the uncertain nature of the claims made in it: "What truth is to journalists, transparency is to bloggers" (Philips 2010. 379). For example, BuzzFeed decided to publish the Steele-dossier (also known as the Trump-Russia dossier) - which alleges that the Russian government possesses compromising information about president Trump and that it colluded with Trump's campaign team during the 2016 presidential election - in its entirety, even though it acknowledged that the allegations in the dossier are "unverified, and potentially unverifiable" (Bensinger et al. 2017). BuzzFeed's actions were considered highly contentious, as they constituted a clear departure from the established journalistic practice to first get the facts straight before publishing. Indeed, the very first point in the Society for Professional Journalists 2014' Code of Ethics speaks of the obligation to "[v]erify information before releasing it" (2014).

Online media, furthermore, view truth as an ongoing process. Posting the story is not the end, as it is with the traditional media. Rather, it is "the start of an online dialogue whereby everyone is free to critique the story and enrich its sources, facts, and perspectives" (Ward 2011. 214). Proponents of the new media thus view journalism as a more cooperative enterprise, to which all can contribute. Finally, they are optimistic about the average citizen's ability to separate truths from falsehoods, reliable online sources of news from peddlers in

\footnotetext{
${ }^{13}$ Seana Shiffrin's thinker-based defense of freedom of speech is a good example of a theory that takes the point of individuals' free speech protection to be the protection and cultivation of agents' autonomy. See: Shiffrin 2014. Chapter Three.

${ }^{14}$ O’Neill 2002. 95; cf. Lichtenberg 1987. 332.
} 
disinformation and fake news. The broad range of news sources to which people have access nowadays is believed to enable them "to develop their critical faculties, which in turn helps them make better choices about what and whom to believe" (Coady 2011. 291).

This new media ethic demonstrates similarities with the familiar "marketplace of ideas" defense of a very broad freedom of expression. It is thought that no institutional filter (i.e. by the press) is needed. Rather, the unimpeded proliferation of news stories online - both verified and unverified, essential and trivial - will contribute to the search for truth. The (online) market of ideas needs no regulation or filter; in fact, it ought not to be regulated or filtered, as that could possibly lead to the withholding of true information. John Stuart Mill held that all information should be allowed to circulate, all opinions expressed, because they may, "for aught we can certainly know, be true. To deny this is to assume our infallibility" (Mill 2008. 59). And even if the information turns out to be false, it is still important that it be published, so that the truth may be challenged and defended by sound arguments. The thought here is that unchallenged truth amounts to dead dogma, rather than reasoned conviction.

This argument for a very expansive freedom of expression (both for individuals and the press) relies on several problematic assumptions, however. It assumes, first of all, that the truth will always come out victorious in the end, invariably driving out falsehoods and prejudices, leaving us only with true beliefs. Mill's defense of free speech thus seems to rely on an idealized understanding of the consumer in the marketplace of ideas. The various consumers in this market proffer reasons for the beliefs they hold, listen to the reasons of others and thus together steadily march towards the truth. Yet, it was Mill himself who taught us that "[m]en are not more zealous for truth than they often are for error." 15 The optimism expressed by proponents of the new media - i.e., that news consumers will only benefit from the proliferation of all kinds of information (including unverified and simply false information) online has proven to be misplaced. Articles like David Coady's (from which I quoted above) were clearly written before the widespread realization that fake news and micro-targeting voters to sway elections present serious threats to democracy, ${ }^{16}$ not only because they undesirably influence democratic elections, but also because they fracture the public sphere. Regarding the latter, the idea that the much broader range of information provided by the new media enriches us by exposing us to different sides of the story, ignores the very real problem of echo chambers and filter bubbles. In practice, only a very narrow spectrum of that broad range of information ever reaches us, as people tend to only visit sites that confirm their own prejudices and world view, and to ignore the rest (Goldman 2008. 120).

As we have seen, the first problematic assumption of the marketplace of ideas justification for a near-absolute press freedom - put forward so often, either implicitly or explicitly, by proponents of the new media ethic ${ }^{17}$ - is that truth will always triumph over falsehood. However, even if we accept this problematic assumption (which we shouldn't), the marketplace of ideas has further problems. By calling for greater transparency and a (near) absolute press freedom, proponents of the new media ethic not only claim that an entirely unimpeded

\footnotetext{
${ }^{15}$ Ibid. 34. Similarly, Bernard Williams has pointed out that "[t] he literal market generates a high level of noise. Everyone knows that in modern conditions of communication messages compete for attention and cancel each other out, and that they are picked out for reasons that need have nothing to do with their truth" (Williams 2002. 215).

${ }^{16}$ The European Commission is, instead, very much aware of the potential danger, as becomes apparent from their recent Communication Tackling Online Disinformation: A European Approach (available at: https:/ec. europa.eu/digital-single-market/en/news/communication-tackling-online-disinformation-european-approach) and from the appointment of a High Level Group on Fake News and Online Disinformation.

${ }^{17}$ See, e.g. Coady 2011. 291.
} 
marketplace of ideas will result in more true beliefs, but also that the search for truth ought to enjoy precedence over other social goods. This is the second problematic assumption; at times, for example, national security concerns may very well outweigh the search for truth and thus justify state secrecy as well as limits upon the scope of press freedom.

Finally, the marketplace of ideas justification seems to think that more information is always better. There may, however, be such a thing as too much information. In order to illustrate this point, consider two distinct ways of handling leaked information: firstly, the information might be leaked to an established media outlet with the required expertise and resources to go through the often vast amount of data, provide the necessary context so that readers may understand what is actually at stake, and execute the necessary redactions in order to minimize the harm that might ensue from rendering the information public (harm, e.g., to national security or to undercover agents in the field). This is how the 11.5 million leaked documents that constitute the Panama Papers were dealt with. The documents were leaked to the German Süddeutsche Zeitung, which shared them with the International Consortium of Investigative Journalists (ICIJ). Subsequently, the ICIJ worked with journalists from over a hundred media organizations in 76 countries to thoroughly analyze the leaked data (BBC 2016). The second way to deal with leaked information is to publish the leaked documents wholesale without making any redactions or providing any context. This is what happened with the more than 150,000 stolen Democratic National Committee e-mails, which were placed online in their entirety by WikiLeaks in 2016.

Here we thus have another difference between the traditional media and certain exponents of the new media. The idea, advocated by BuzzFeed and WikiLeaks among others, that one can simply, in the interest of general transparency, go ahead and publish the information one has without providing the necessary context, without distinguishing the important from the trivial, and without verifying all the information, so that individual readers may decide for themselves what is true and what false, what important and what inconsequential, in fact achieves the exact opposite of what it purportedly strives to achieve, as O'Neill makes clear: "Increasing transparency can produce a flood of unsorted information and misinformation that provides little but confusion unless it can be sorted and assessed" (O’Neill 2002. 72-3). Such information glut effectively undermines our ability to focus and understand. Disclosure of information is worth very little if the intended recipients do not properly receive and comprehend it. Indeed, placing vast amounts of information online, uncurated and without context, does nothing to further knowledge or to enable citizens to fulfil their civic obligations. Publishing often quite elaborate leaks without context will lead not to more understanding, but rather to a "glut of questionable information that functions, somewhat unexpectedly, as its own form of censorship, rather than as a way to illuminate the maneuverings of the powerful" (Tufekci 2016).

In sum, the new media ethic (taking its cue from the marketplace of ideas justification for free expression) assumes that (1) in an entirely free market of ideas truth will always triumph over falsehood; (2) truth ought to always enjoy precedence over other social goods; and (3) more information is always better, i.e. more conducive to the discovery of the truth. All three assumptions have been shown to be untenable. The argument, based on the marketplace of ideas model, against limiting press freedom in the interest of democracy is, therefore, refuted. The argument put forward in Section 2 for certain limits to the freedom of the press, therefore, still stands. In response, some might concede that absolute press freedom has its problems but argue that we simply cannot trust the government to regulate the press in the appropriate manner. The worry is that it might be tempted, for example, to censor articles that are critical of 
its policies. Or else one might fear that the government is simply not capable of properly distinguishing hate speech from acceptable speech, or properly informed journalism from fake news and propaganda. It's unclear, however, why government would be uniquely suspect or incapable concerning matters involving speech. If government is generally held to be capable of regulating markets and products, for example, in a way that aims to benefit public utility, it should also be considered competent to regulate the press with the same aim in mind. Moreover, we should be clear that regulation of the press is not the same as government control of the press. There are, for example, regulations that dairy products, medicine, and cars have to comply with, but that does not mean that the government determines what products dairy farmers, pharmaceutical companies and car companies ought to develop. Rather, regulations for these products are merely meant to ensure that those products benefit, or at least do not harm public health or public safety. Similarly, regulations for the press do not lead to government control of the press; all they are meant to do, is ensure that the press's "products" enable the public to exercise its political rights in an informed manner or, at least, that they do not hinder that ability (in the way that, say, misinformation does) or otherwise harm the public interest. $^{18}$

Finally, what are the alternatives to government regulations for the press? Either no regulation at all, which I have argued is undesirable, or self-regulation by the media, including the online media and social network platforms, such as Facebook and Twitter. Self-regulation, however, often has detrimental consequences for press freedom. When confronted with considerable fines for allowing unlawful speech to remain on their platform, media companies tend to err on the side of caution. As a result, lawful speech is often also removed. In Germany, for example, the new NetzDG law requires social media platforms to remove potentially illegal material or face a fine of up to $€ 50$ million. As a result, the German satirical magazine Titanic was barred by Twitter after it parodied anti-Muslim comments on its Twitter account Scott and Delcker (2018). This trend of governments outsourcing regulation to the media companies themselves thus tends to lead to more censorship due to those companies' tendency to overremove content. This is extremely worrying, because, as Daphne Keller explains, "[t]his pattern of over-removal becomes more consequential as private platforms increasingly constitute the 'public square' for important speech" (Keller 2018. 2).

In conclusion, both self-regulation and no regulation have been shown to be problematic, leaving the way free for government regulation of the press in the public interest, as argued for in Section 2.

\section{What Public Interest?}

Typically, both whistleblowers and members of the press are viewed (and view themselves) as servants of the public interest. Regarding the former, political philosophers, ${ }^{19}$ legal scholars (Benkler 2014; Kagiaros 2015), whistleblower protection laws, ${ }^{20}$ and the courts ${ }^{21}$ all agree that a whistleblower's breach of state secrecy by disclosing classified documents is justified if it serves the public interest. Similarly, the news media are considered to be "watchdogs of the

\footnotetext{
18 The next section will clarify what I mean by "the public interest".

${ }^{19}$ Boot 2017; Delmas 2014. 62; Kumar and Santoro 2017. 8ff.; Sagar 2013. 13.

${ }^{20}$ The UK Public Interest Disclosure Act; the Dutch Wet Huis voor klokkenluiders (House for Whistleblowers Act), article 1(d).

${ }^{21}$ E.g., Guja v. Moldova [Grand Chamber], no. 14277/04, European Court of Human Rights 2008. § 74.
} 
public interest;" they safeguard the public interest by questioning the claims government officials make, thus holding them to account, and by providing citizens with the information needed to exercise their political rights in an informed fashion. ${ }^{22}$ Furthermore, when journalists employ methods that seem unethical at first glance - such as publishing a story based on information leaked illegally to the press - they may justify their actions by appealing to the public interest served by their actions (Cohen-Almagor 2001. 92-3). There are two problems with this story, however: firstly, it may be true that, generally speaking, the press serves the public interest by, as argued in Section 2, informing citizens of matters that are essential for the fulfillment of their democratic duties. Yet, there are cases, in which, instead, the press serves the public interest (or particularly weighty private interests), by not publishing certain information, that is, by respecting certain limits to its freedom of expression, where publication would amount to harming the public interest. There are, of course, various harmful forms of expression (hate speech, propaganda, misinformation), but my focus here is on the press's treatment of leaks. Not only will I ask whether the publication of unverified leaked information is permissible, but also whether there are any constraints on the permissibility of publishing verified leaks (e.g., because publication might harm national security). For example, say a journalist obtains information concerning the manner in which the intelligence services keep tabs on terrorists. The public interest in national security is most likely better served by not (yet) rendering this information public, as publication could inform the terrorists as well, leading them to switch communication methods. ${ }^{23}$

The second problem with the media justifying their actions by referring to the public interest is that, though it is often appealed to, the concept of the public interest is never defined. In this section and the next I aim to solve both problems. Accordingly, this section will first provide a clarification of the public interest and the following section will explicate the conditions under which the news media ought to refrain from publishing leaked classified information.

Before expounding my account of the public interest, allow me to discuss three of the most dominant public interest theories and point out their strengths and weaknesses. ${ }^{24}$

\subsection{The Aggregative Theory ${ }^{25}$}

According to the aggregative theory, the public interest consists simply of "the sum of the interests of the several members who compose it" (Bentham 1996. 12). In order to determine whether a particular law or policy is in the public interest we must determine its effects on the welfare of each of the individual members of the public and tally the results. If, on balance, the law or policy benefits more individuals than are harmed by it, this will demonstrate the "general good tendency of the act, with respect to the total number or community of individuals concerned." 26

\footnotetext{
${ }^{22}$ Norris 2014. 525ff.

${ }^{23}$ This actually happened in 2013 when news reports revealed that the U.S. had intercepted communications between Ayman al-Zawahri, the head of Al Qaeda, and Nasser al-Wuhayshi, the head of the Yemen-based Al Qaeda in the Arabian Peninsula, in which the two discussed an imminent terrorist attack. After those reports, analysts noted a sharp decline in the terrorists' use of a major communications channel that U.S. authorities had been monitoring (Schmitt and Schmidt (2013)).

${ }^{24}$ For a more elaborate treatment of these various public interest theories, see Boot 2019.

${ }^{25}$ For this list of public interest theories, I am draw from Held 1970 and Mansbridge 1998, though I depart from both of their lists.

26 Ibid. 40.
} 
The problem with this account of the public interest is that we often want to distinguish between the preference of a majority and the public interest. Furthermore, the aggregative theory may be considered morally objectionable, as it appears to consider minority interests inferior to majority interests, irrespective of their content. Moreover, can we expect the aggregation of private interests to ever yield a genuinely public interest or will the result instead be "nothing but a sum of particular wills?"27 Finally, there is the familiar problem raised by social choice theory, namely that when voters have to make a choice between three or more alternatives, there is no fair and rational way to determine which of these is preferred by a majority, that is, to convert voters' preferences into a social decision. ${ }^{28}$ There are thus worries concerning the theory's practical feasibility.

\subsection{The Procedural Theory}

In brief, the procedural theory argues that whatever is the outcome of a deliberative democratic process is in the public interest. ${ }^{29}$ Though the deliberators still start out with their own private interests, the hope is that the deliberative process - in which one has to, among other things, give reasons for one's position that others could deem acceptable - will transform those private interests so that the final result of deliberation (the law or policy decided upon) will be in the public interest. The procedural approach thus hopes to distill the public interest from a plethora of private interests through democratic deliberation.

Here, again, the problem is that the public interest is derived from individual, private interests. Proceduralists may hope that the deliberative process will somehow transform private interests into public interests, but this is questionable. Furthermore, the strict equation of the public interest with the outcome of deliberation is problematic; we have no guarantee that participants will deliberate judiciously and that the result will be satisfactory.

The strong point these two theories of the public interest share is that they allow for conflicts between individual interests and the public interest. My private interest may very well differ both from the majority interest and from the result of deliberation. The two theories, however, also share a considerable weakness, namely their individualistic nature. They both start from private, individual interests, rendering it doubtful that they will ever yield a genuinely public interest.

\subsection{The Unitary Theory}

To avoid the problem of individualism, consider the unitary theory. This theory does not derive the public interest from people's private interests, but rather from a comprehensive moral theory that applies equally to private and public interests. Consequently, a law or policy cannot be in the public interest if it is not in the interest of all, and it cannot truly be in the interest of individuals if it is not in the public interest. Accordingly, there can be no justifiable conflict between individual interests and the public interest. This, for example, was Aristotle's position. The end at which the state aims - the good it strives to bring about - coincides with the end each individual ought to strive towards: "the best life, whether separately for an individual or

\footnotetext{
${ }^{27}$ Rousseau 1997. Bk. III, Ch. 3 [2].

${ }^{28}$ See, e.g., Arrow 1963.

${ }^{29}$ See, e.g. Cohen 1989. 25: "the interests, aims and ideals that comprise the common good are those that survive deliberation.” Cf. Benhabib 1996. 69.
} 
collectively for states, is the life conjoined with virtue furnished with sufficient means for taking part in virtuous actions," that is, human flourishing (eudaimonia) (Aristotle 1944).

Though the unitary theory does not problematically derive the public interest from individual, private interests, it suffers from different drawbacks. First, its predisposition to paternalism - it dismisses as misguided any assertion of a private interest that does not coincide with the public interest - and, secondly, its exclusion of conflicting interests. In modern pluralistic societies, no unanimity concerning private interests can be presumed; assuming a unity between the individual and the collective good is, therefore, untenably problematic.

\subsection{The Civic Theory}

This brief discussion of public interest theories yields the following desiderata for a convincing theory of the public interest:

1. It must allow for conflicting interests.

2. It cannot start from private, individual interests.

3. It cannot derive the public interest from a comprehensive doctrine.

I believe my account of the public interest - the civic account - can meet these desiderata. The civic theory of the public interest draws from Brian Barry's suggestion that the public interest concerns "those interests which people have in common qua members of the public" (Barry 1965. 190). We all inhabit sundry roles: employee, parent, homeowner, citizen. A particular fiscal policy may harm my interests as a homeowner, for example, but, according to the proposed account, in my capacity as citizen I ought to consider only what effect the measure will have on society as a whole. This approach (1) does not deny a multitude of different and often conflicting private interests in society, yet it states that (2), in determining the public interest, we ought to pay heed only to the interests that all share as members of the public. For example, though some, qua owners of polluting industries, have a private interest that deviates from that of most others - namely, an interest in lax air quality regulations -, in their role as citizen they share an interest in clean air with all other members of the public. Regulation ensuring clean air is, therefore, in the public interest "in the sense that it is in everyone's interest qua member of the public." 30

Furthermore, Barry's approach occupies (3) attractive middle ground between the comprehensive moral position advocated by the unitary theory and the subjectivist nature of the aggregative and procedural theories. The public interest is not simply the aggregate of private interests nor is it to be equated to the outcome of deliberation. Rather, the public interest is a moral concept in the sense that private interests are excluded from its determination: in determining the public interest, we ought to pay heed only to our interests as members of the public. Yet, it does not presuppose wide agreement over a comprehensive moral theory as the unitary theory seems to do. This approach thus meets all three desiderata.

However, Barry, problematically, does not specify which interests we share qua citizens. I maintain that the only interests we can reasonably be said to all share in our role as members of the public are interests in conditions that render it possible for each of us to develop and strive to realize our own values, objectives, and life plans. For example, if a ruler is allowed to

${ }^{30}$ Ibid. 224. 
exercise his power in an unchecked and arbitrary manner, it becomes very difficult to draft a life plan, let alone realize it, given that we do not know for sure that what is permissible today won't be decreed impermissible tomorrow. Hence, the shared interest in the rule of law. Similarly, we require a sphere of protected free agency to be able to formulate and realize a life plan. We thus share an interest in fundamental human rights. ${ }^{31}$ Further examples of interests we share qua members of the public include interests in political accountability and national security.

These shared interests may of course clash. In such cases, it is important to remember that the public interest is a comparative concept: “'Being in someone's interest' is at least a triadic relationship between a person and at least two policies" (Barry 1965. 192). So in order to determine whether a given policy is in the public interest, we must determine whether it is more in the public interest than a given alternative. In order to judge whether, for example, publishing leaked classified information better serves the public interest than continued secrecy, we must look at the extent of the harm done to national security, say, and the significance of the benefit to political accountability. If the latter is rather large, whereas the former is quite small, then it would seem publishing the leaked information is more in the public interest than continued secrecy.

\section{To Publish or Not to Publish?}

Now that we have a better understanding of the public interest that both whistleblowers and journalists are held to serve, let us consider two actual publications of leaked information and determine whether they were in the public interest. If they were not, I argue they do not fall within the bounds of the press's freedom of expression.

For our first example, let us take another look at BuzzFeed's publication of the TrumpRussia dossier. BuzzFeed editor in chief Ben Smith justified the decision to publish the "unverified, and potentially unverifiable" document containing serious allegations against the sitting president of the United States by pointing out that BuzzFeed provided sufficient context by stating explicitly that the allegations in the document are unverified and that the report "contains errors." 32 Furthermore, Smith argued that BuzzFeed was meeting the readers' expectation for transparency: "You trust us to give you the full story; we trust you to reckon with a messy, sometimes uncertain reality" Smith (2017). In an age with so much misinformation and outright propaganda, however, the question is whether we can really trust that the average news consumer is capable of dealing with that messy reality. One could argue, instead, that we rely on journalists to clarify that messy reality for us, not compound its complexity. Smith maintained that readers "want to be trusted to judge dubious documents," 33 yet, as I argued in Section 3, the media landscape has become so complex that such judgment becomes increasingly difficult. Recent research has shown, for example, that students (though they are likely not the only ones) have trouble judging the credibility of information online (Wineburg et al. 2016). Providing them and others with an unsorted mix of verified and unverified, trivial and important information is, therefore, likely to lead to false beliefs. This damages the public

\footnotetext{
31 This includes socio-economic rights, given that a certain level of physical well-being is a necessary precondition for the possibility of developing and striving to realize a life plan.

32 Bensinger et al. 2017.

33 Ibid.
} 
interest in political accountability, as uninformed or misinformed citizens cannot adequately hold their leaders to account.

We can imagine Smith and others countering with appeals to the public interest in transparency. Transparency in itself, however, is of little value. It is valuable only insofar as it enhances accountability. For it to have that effect, the information made available has to be true. In this case, BuzzFeed did not know whether all the information in the published report was true (nor do we know now, two years later). The publication, therefore, did not serve the interest we share as members of the public in accountability. What it did do, is play into the hands of those who, including the president himself, try to discredit the press in general by referring to it as "fake news." BuzzFeed's decision to publish the report undoubtedly gave further credence, in the eyes of some, to the notion that the mainstream media are anti-Trump, rather than independent and neutral news providers. By harming the credibility of the press in general, BuzzFeed's publication of unverified leaks in fact harmed the public interest in accountability: if trust in the media's credibility decreases, so too does the public's knowledge of its government's actions (as people will no longer consult or else believe the media) and so its ability of holding its leaders to account. BuzzFeed's publication of the Trump-Russia dossier, therefore, harmed the public interest and should, therefore, not be considered protected by the freedom of the press.

Now consider a case in which verified leaks were published. In 2013 Edward Snowden leaked approximately 1.7 million U.S. government classified documents (Strohm and Del Quentin 2014) to journalists for The Guardian and The Washington Post (the former of which later enlisted the help of journalists for ProPublica and The New York Times). Among other things, these documents showed that Americans' phone and internet records were being monitored on a truly massive scale. The mentioned journalistic outlets, and many others after them, published numerous stories clarifying, e.g., the scope of the NSA's bulk data collection program. The journalists did not, however, simply place the documents Snowden had leaked to them online in their entirety, contrary to, say, BuzzFeed's publication of the Trump-Russia dossier or WikiLeaks' release of the 2016 Democratic National Committee email leak. Let us now consider whether the publications based on Snowden's leaks ought to have been protected by the press's freedom of expression. Did, in other words, these publications serve or damage the public interest?

Government surveillance, whereby citizens' telephone and internet records were monitored on a massive scale, is certainly a matter of public concern. Fundamental rights, such as the right to privacy, were curtailed by these government policies, putting at risk the interest we share as members of the public in having a sphere of protected free agency, which is ensured by fundamental rights. Eventually, the news stories on Snowden's leaks led to several lawsuits, whereby a U.S. District Court Judge found the NSA's data collection program to be unconstitutional for violating the Fourth Amendment (Gerstein 2013) and a federal appellate court ruled that the NSA's bulk collection of communications records was illegal (Stempel 2015). These rulings seem to indicate that the stories based on the documents leaked by Snowden did indeed help address government wrongdoing, thereby serving the public interest.

In addition, the decision to publish about Snowden's leaks also benefited the public interest in democratic self-governance. By informing the public of these government programs, the media sparked a debate concerning the proper bounds of government surveillance on the one hand and the scope of fundamental rights on the other. This debate also reached Congress itself, which passed the USA Freedom Act, introducing vital reforms to the NSA's bulk data collection program. We may conclude that though a policy that infringes upon fundamental 
human rights may be justified, there ought to be some form of public discussion concerning the policy's desirability, if it is to have a democratic pedigree. ${ }^{34}$ The reporting on the information leaked by Snowden was crucial in making that public debate happen.

Finally, if citizens are left in the dark concerning certain government policies they would deem unjust if they only knew about them, they cannot voice their disagreement or vote politicians out of office. Therefore, by informing the public of secret government policies that impact fundamental rights, the press additionally benefited the shared interest in public accountability.

It is thus clear that the publishing of news articles based on the information leaked by Snowden certainly benefited the public interest. Yet, we still need to consider whether those articles harmed a different shared interest, namely that of national security, and whether that harm outweighs the benefits to the other shared interests mentioned above. The President's Review Group on Intelligence and Communications Technologies has maintained that some of the bulk data collection programs disclosed by Snowden did actually play a role in preventing terrorism. Section 702 of the Foreign Intelligence Surveillance Act, for example - allowing the targeting of the communications of non-U.S. persons residing outside of the United States for foreign intelligence purposes (though indirectly it may also target the international communications of U.S. citizens) - has helped gather intelligence which led to over 50 counterterrorism investigations. The President's Review Group writes that Section 702 did in fact "play an important role in the nation's effort to prevent terrorist attacks across the globe" 35 and worries that the exposure of this program may have inhibited its functioning. On the other hand, Section 702 was reauthorized in January 2018, which seems to indicate that the publications on Snowden's leaks did not greatly affect the program's efficacy, at least not in the long term. Indeed, the harm caused by publications on the Snowden leaks was likely limited to the "adaptation of techniques to recover lost effectiveness" (Benkler 2014. 322). It seems unlikely that such a limited and, apparently, temporary cost would outweigh the more expansive and lasting benefits to the interests we share as citizens in fundamental rights, political accountability and democratic self-governance. In conclusion, the news articles on Snowden's leaks benefited the public interest more than they harmed it and so ought to be protected by the press's freedom of expression.

\section{Conclusion}

The aim of the present article has been to address some of the most pressing questions concerning the thus far neglected (at least by political philosophers) role of the media in unauthorized disclosures of secret information. The main overarching aim was to demonstrate that media workers' freedom of expression is, at least morally speaking, more limited than commonly thought, and to explore the precise scope of that freedom with respect to the media's treatment of leaks.

\footnotetext{
34 This is not to say that the government should have rendered each and every detail concerning the secret data collection program public, as that might have undermined the policy's functioning or endangered national security. Often, however, the government can disclose the general contours of a secret policy, which can safely be the subject of public debate. Dennis Thompson refers to this as "partial secrecy" (Thompson 1999).

35 The President's Review Group on Intelligence and Communications Technologies. 2013. Liberty and Security in a Changing World. December 12. 145.
} 
Section 1 argued that the difference in treatment between whistleblowers and the journalists publishing their disclosures makes sense given the different special obligations they are under. Section 2 made clear that though media workers have a far more extensive right to freedom of expression than government employees (as demonstrated in Section 1), this right is not without limits. Press freedom, as opposed to individuals' right to freedom of expression, is an instrumental good. Specifically, it is only a good insofar as it serves to inform the public of matters of public interest, enabling citizens to perform their democratic duties in an educated manner. Accordingly, the freedom of the press is subject to more restrictions than the freedom of expression of individuals. Subsequently, Section 3 discussed a common argument for a very expansive press freedom, and so against the more limited scope of press freedom argued for in Section 2, based on the marketplace of ideas model. This argument, put forward by some of the proponents of the new online media, was found to be untenable, however. In the course of refuting this argument, Section 3, furthermore, compared the ethics of the traditional and the new online media.

As the public interest is often appealed to by journalists employing methods that at first glance do not seem entirely ethical - such as publishing articles about leaked state secrets -, Section 4 set out to clarify the concept of the public interest by, first, providing an overview of several public interest theories and, second, putting forward a new, more convincing theory of the public interest: the civic theory. It, furthermore, argued that the public interest can also compel media workers to not publish a story, in the interest of national security, for example. Finally, Section 5 discussed two leaks - one of unverified information and one of verified information - in order to demonstrate how we might judge the permissibility of publishing about leaked classified information in practice. By spelling out the relevant interests we all share qua members of the public, as well as the publication's effect on each of those shared interests, we can conclude whether a publication about leaked information is in the public interest, all things considered. If not, then the publication ought not to be protected by the press's freedom of expression.

Open Access This article is distributed under the terms of the Creative Commons Attribution 4.0 International License (http://creativecommons.org/licenses/by/4.0/), which permits unrestricted use, distribution, and reproduction in any medium, provided you give appropriate credit to the original author(s) and the source, provide a link to the Creative Commons license, and indicate if changes were made.

\section{References}

Aristotle (1944) Politics. Translated by H. Rackham. Cambridge (Mass): Harvard University Press. VII.i $1323 \mathrm{~b} 40-1324 \mathrm{a} 2$

Arrow KJ (1963) Social choice and individual values, 2nd edn. Yale University Press, New Haven

Barry B (1965) Political argument. Routledge \& Kegan Paul, London

Benhabib S (1996) Toward a deliberative model of democratic legitimacy. In: Benhabib S (ed) Democracy and difference: contesting the boundaries of the political. Princeton University Press, Princeton, pp 67-94

Benkler Y (2011) A free irresponsible press: Wikileaks and the Battle over the soul of the networked fourth estate. Harv. C.R.-C.L. L. Rev. 46:311-397

Benkler Y (2014) A public accountability defense for National Security Leakers and whistleblowers. Harv. L. \& Pol'y Rev. 8:281-326

Bensinger, Ken, Miriam Elder, and Mark Schoofs. 2017. These reports allege trump has deep ties to Russia. BuzzFeed, January 10. Available at: https://www.buzzfeednews.com/article/kenbensinger/these-reportsallege-trump-has-deep-ties-to-russia\#.bsDZnK5E3 
Bentham, J (1996). An introduction to the principles of morals and legislation. Edited by J. H. Burns and H. L. A. Hart. Oxford: Oxford University Press

Boot ER (2017) Classified Public Whistleblowing. Social Theory and Practice 43(3):541-567aaa

Boot ER (2019) The Feasibility of a Public Interest Defense for Whistleblowing. Law and Philosophy. Forthcoming

Cannie H, Voorhoof D (2011) The abuse clause and freedom of expression in the European human rights convention: an added value for democracy and human rights protection? Neth. Q. Hum. Rights 29:54-83

Coady D (2011) An epistemic Defence of the blogosphere. J Appl Philos 28:277-294

Cohen J (1989) Deliberation and democratic legitimacy. In: Hamlin A, Pettit P (eds) The good polity: normative analysis of the state. Basil Blackwell, Oxford, pp 17-34

Cohen-Almagor R (2001) Speech, media and ethics: the limits of free expression. Palgrave Macmillan, Basingstoke

Delmas C (2014) The civic duty to report crime and corruption. Les ateliers de l'éthique 9:50-64

Delmas C (2015) The ethics of government whistleblowing. Soc Theory Pract 41:77-105

Gerstein J (2013). Judge: NSA program likely unconstitutional. Politico, December 12. Available at: http://www. politico.com/story/2013/12/national-security-agency-phones-judge-101203

Goldman AI (2008) The social epistemology of blogging. In Information technology and moral philosophy, ed. Jeroen van den Hoven and John Weckert, 111-122. Cambridge: Cambridge University Press

Greenawalt K (2016) “Clear and present danger" and criminal speech. In: From the bottom up: selected Essays. Oxford University Press, New York, pp 337-355

Hardimon MO (1994) Role obligations. J Philos 91(7):333-363

Harris NGE (1990) Journalists: a moral law unto themselves? J Appl Philos 7:75-85

Held V (1970) The public interest and individual interests. Basic Books, New York

Kagiaros D (2015) Protecting "National Security" whistleblowers in the Council of Europe: an evaluation of three approaches on how to balance National Security with freedom of expression. The International Journal of Human Rights 19:408-428

Keller D (2018) Internet platforms: observations on speech, danger, and money. Hoover Institution Aegis Series Paper No. 1807

Kitrosser H (2008) Classified information leaks and free speech. Univ Ill Law Rev 2008:881-931

Kumar M, Santoro D (2017) A justification of whistleblowing. Philos. Soc. Crit. 43:669-684

Lichtenberg J (1987) Foundations and limits of freedom of the press. Philosophy \& Public Affairs 16 . Wiley, pp $329-355$

Mansbridge J (1998) On the contested nature of the public good. In Private action and the public good, ed. Walter W. Powel and Elisabeth Stephanie Clemens, 3-19. New Haven: Yale University Press

Mill JS (2008) On liberty. In: Gray J (ed) On liberty and other essays. Oxford University Press, New York, pp 1128

Norris P (2014) Watchdog journalism. In: Bovens M, Goodin RE, Schillemans T (eds) The Oxford handbook of public accountability. Oxford University Press, Oxford, pp 525-541

O’Neill O (2002) A question of trust: the BBC Reith lectures 2002. Cambridge University Press, Cambridge

O’Neill O (2008) Conceptions of press freedom in a globalising world. Available at: https://www.repository.cam. ac.uk/bitstream/handle/1810/241043/Press_freedom_oneill_2008.pdf?sequence=1\&isAllowed=y

Panama Papers Q\&A (2016) What Is the Scandal About? 2016. BBC, April 6. Available at: https://www.bbc.co. uk/news/world-35954224

Philips A (2010) Transparency and the new ethics of journalism. Journal Pract 4:372-382

Quinlan M (1993) Ethics in the public service. Governance 6:538-544

Rousseau J-J (1997) Of the social contract. In: Gourevitch V, Gourevitch t V (eds) The social contract and other later political writings. Cambridge University Press, Cambridge, pp 39-152

Sagar R (2013) Secrets and leaks: the dilemma of state secrecy. Princeton University Press, Princeton

Scheuerman WE (2014) Whistleblowing as civil disobedience: the case of Edward Snowden. Philos. Soc. Crit. 40:609-628

Schmitt E, Schmidt MS (2013, September 29). Qaeda plot leak has undermined U.S. intelligence. The New York Times. Available at: https://www.nytimes.com/2013/09/30/us/qaeda-plot-leak-has-undermined-usintelligence.html

Scott M, Delcker J (2018, January 6). Free speech vs. censorship in Germany. Politico. Available at: https://www. politico.eu/article/germany-hate-speech-netzdg-facebook-youtube-google-twitter-free-speech/

Shiffrin SV (2014) Speech matters: on lying, morality, and the law. Princeton University Press, Princeton

Shiffrin S (2017) The moral neglect of negligence. In: Sobel D, Vallentyne P, Wall S (eds) Oxford studies in political philosophy, vol 3. Oxford University Press, Oxford, pp 197-228

Smith B (2017, January 23). Why BuzzFeed news published the dossier. The New York Times. Available at: https://www.nytimes.com/2017/01/23/opinion/why-buzzfeed-news-published-the-dossier.html 
Society for Professional Journalists (2014) Code of ethics. Available at: https://www.spj.org/ethicscode.asp. Accessed 30 May 2019

Stempel J (2015) NSA's phone spying program ruled illegal by appeals court. Reuters, May 7. Available at: http://www.reuters.com/article/us-usa-security-nsa-idUSKBN0NS1IN20150507

Stone GR (2007) Government secrecy vs. freedom of the press. Harv. L. \& Pol'y Rev. 1:185-217

Strohm C, Del Quentin W (2014) Pentagon says Snowden took most U.S. Secrets ever: Rogers. Bloomberg News, January 10. Available at: https://www.bloomberg.com/news/articles/2014-01-09/pentagon-findssnowden-took-1-7-million-files-rogers-says

Thompson DF (1999) Democratic secrecy. Political Science Quarterly 114:181-193

Tufekci Z (2016) WikiLeaks isn't whistleblowing. The New York Times, November 4. Available at:https://www. nytimes.com/2016/11/05/opinion/what-were-missing-while-we-obsess-over-john-podestas-email.html

Ward SJA (2011) Ethics and the media: an introduction. Cambridge University Press, Cambridge

Weber M (1991) Politics as a vocation. In Essays in sociology, ed. H. H. Gerth and C. Wright Mills, tran. H.H. Gerth and C. Wright Mills, 77-128. London: Routledge

Williams B (2002) Truth and truthfulness: an essay in genealogy. Princeton University Press, Princeton

Wineburg S, McGrew S, Breakstone J, Ortega T (2016) Evaluating information: The cornerstone of civic online reasoning. Stanford digital repository. Available at: http://purl.stanford.edu/fv751yt5934

Publisher's Note Springer Nature remains neutral with regard to jurisdictional claims in published maps and institutional affiliations. 